Original article

\title{
Unveiling the underprintings of a late-fifteenth-early-sixteenth century illuminated French incunabulum by infrared reflectography
}

\author{
Catarina Miguel ${ }^{\mathrm{a}, *}$, Silvia Bottura ${ }^{\mathrm{a}}$, Teresa Ferreira ${ }^{\mathrm{a}, \mathrm{b}}$, Antónia Fialho Conde ${ }^{\mathrm{c}, \mathrm{d}}$, \\ Cristina Barrocas-Dias ${ }^{\mathrm{a}, \mathrm{b}}$, António Candeias ${ }^{\mathrm{a}, \mathrm{b}}$ \\ ${ }^{a}$ HERCULES Laboratory, Institute for Advanced Studies and Research, Universidade de Évora, Largo Marquês de Marialva 8, 7000-809 Évora, Portugal \\ ${ }^{\mathrm{b}}$ Chemistry Department at Science and Technology School, Universidade de Évora, Rua Romão Ramalho, 59, 7000-671 Évora, Portugal \\ ' CIDEHUS, Universidade de Évora, Largo Marquês de Marialva 8, 7000-809 Évora, Portugal \\ ${ }^{\mathrm{d}}$ History Department at Social Sciences School, Universidade de Évora, Largo dos Colegiais 2, 7000-803 Évora, Portugal
}

\section{A R T I C L E I N F O}

\section{Article history:}

Received 9 April 2018

Accepted 21 May 2019

Available online 21 June 2019

\section{Keywords:}

Infrared reflectography

Incunabulum

Underprintings

Book of Hours

Chemical analysis

\begin{abstract}
A B S T R A C T
For the first time, IR reflectography was used for analysing the production technique of incunabula, unveiling impressive results concerning the identification of underprintings and the relation with its coloured illuminated representations. In this work, the procedures followed for producing a late-fifteenth-earlysixteenth century incunabulum produced in the Parisian workshop of Germain Hardouyn held by the Biblioteca Pública de Évora (Inc.438) were characterized by IR reflectography. Unexpected features concerning the creative process of the hand-coloured procedures were achieved, reflecting an illuminator strongly influenced by the devotions that were in fashion at the time, unlike the engraving plates used on the incunabulum, whose representations faithfully followed the references of the Holy Scriptures. For the evaluation of the originality of the painted surfaces, a representative painted illustration - the Adoration of the Magi, f.11 - was full characterized using a microscopic and spectroscopic approach (OM, SEM-EDS, Raman microscopy, $\mu$-FTIR). Three representative coloured-paints (white, blue and gilding) of the painted illustrations from the Adoration of the Magi (f.11), the Pietà $(f .47 \mathrm{v})$ and the Pentecost $(f .65 \mathrm{v})$ were characterized and compared to infer on the contemporaneity of these painted illustrations.
\end{abstract}

(c) 2019 Elsevier Masson SAS. All rights reserved.

\section{Introduction}

Before the creation of the printing process, written books were mainly restricted to a small number of people from the highest levels of society. It was only around 1450 s, with the invention of the printing press by Guttenberg, that books and written knowledge became accessible to a larger number of people across Europe. The first printed books - the incunabula - were books produced in the transition from the medieval hand painted technique to the printing process. Their production included the printing of a composed text on the support (parchment or paper), that could be complemented with images printed from engraved copper or lead plates, which, themselves, could be composed of several plates [1]. Some of these images could be complemented with decorative frames, also printed from engraved metallic plates [2]. In this sense, the same frame composition - or fragments of composition - could be used to frame other images along the incunabulum, or in different

\footnotetext{
* Corresponding author.

E-mail address: cpm@uevora.pt (C. Miguel).
}

incunabula. The reuse of the printing plates was a common procedure in these early printing workshops. For the printing process, carbon black (namely soot or lampblack pigments) was commonly added to iron gall ink to produce a relative thick ink, fundamental for the covering effectiveness of the printing process [3]. By enlarging the scale of production and reducing time and costs of production, the printed books became available to a higher number of persons, allowing those who were not able to own a manuscript before, to be able to acquire it now. Nevertheless, manuscripts were still largely desired, namely for its brightness, uniqueness and singularity. In this sense, the practice of illuminating printed books following similar techniques as those used to produce manuscripts' illuminations was frequent. Commonly used for the private devotion of the highest levels of society, Books of Hours were among the first texts to be produced as incunabula [4,5].

The study of incunabula production is still in its starting point. In the last two decades, some studies were performed concerning the elemental composition of the printing inks and paper leaves used by Hardouyn printers $[3,6]$. Nevertheless, none of these studies concerned the analysis of the underprintings nor the illumination procedure followed at the time of its production. The Biblioteca 
Pública de Évora (BPE) preserves a set of unique incunabula produced during the late-fifteenth-first half of the sixteenth century in French printing workshops [7]. The Inc. $438(170 \times 103 \mathrm{~mm})$ is a Book of Hours printed on parchment in Paris by Germain Hardouyn which, in the early twentieth century, became part of the BPE collection [8]. It presents a set of 30 painted illustrations of different sizes and shapes, printed and then hand painted most probably at the time of its production. IR-reflectography has been widely used for underdrawings analysis in paintings, namely on canvas and wood paintings [9-12]. Although widely used for the analysis of sublayers, IR-reflectography does not provide reliable information on the estimation of the depth of the detected sublayers [13]. This is a technique of extreme importance for the Art History field, for what can be perceived from the specificities of the preparatory drawings, process for the drawing transfer, constructions of the paints strokes, artists' signatures, hidden inscriptions or any other details that may fingerprint the technique of a specific artist and/or workshop, or even missing texts in ancient papyrus $[9,10,12,14,15]$. Recent studies used IR reflectography to discriminate between handwritten and printed texts in 15th-17th century book production, based on the differences of contrast between carbon-based inks (printed text), iron-gall inks (handwritten text) and paper support [15]. This approach has also been followed for examining carbon-based inks on parchment, since the contrast between the ink and the support is usually considerable in this infrared spectral region [14]. The contrast between black carbon-ink and white-yellowish parchment depends on the layers' transparency (restricted by the grain size, concentration of the pigment, binding media and layer thickness) and the existence of enough reflecting ground [16].

In this work, IR reflectography was used for the analysis of the underprintings of a set of three representative painted illustrations from Inc.438, with unexpected results concerning the matching of the underprintings iconography and the final painted illustrations. Aiming to evaluate the originality of the painted surfaces and its contemporaneity to the printed representations, microscopic and spectroscopic analysis (Optical microscopy, SEMEDS, Raman microscopy, $\mu$-FTIR) were used on a representative painted illustration-the Adoration of the Magi (f.11). Fig. 1 displays in a schematic way the experimental design followed on the physical-chemical analysis of the Adoration of the Magi, f.11.

To provide information on the contemporaneity of the painted illustrations of the Adoration of the Magi (f.11), the Pietà $(f .47 \mathrm{v})$ and the Pentecost (f.65v), a similar approach as described in Fig. 1 was followed for the elemental and molecular characterization of three representative colour paints: white, blue and gilding.

\section{Research aim}

The use of infrared reflectography analysis for characterizing the underprintings by Hardouyn's workshop in Inc. 438 will allow a unique comparison between printed and painted illustrations.

Being the late-fifteenth-early-sixteenth century a period of transition for devotional iconography due to the influence of the Council of Trent (1545-1563), it will be interesting to infer whether the illuminator was more or less influenced by the devotions that were in fashion at the time, and in which sense the engraving plates' representations faithfully followed the references of the Holy Scriptures. To infer on the originality of the painted illustrations, selected colour paints from the Adoration of the Magi, the Pietà and the Pentecost are characterized in a molecular point of view.

\section{Materials and methods}

The study started with a detailed observation of the illuminations under a stereomicroscope to evaluate the underprintings that could be observed under the most transparent painted regions, the state of conservation of the coloured paints and to establish possible areas for micro-sampling. For a selected set of representations, IR reflectography was performed over the painted illustrations. To enhance the readability of the underprintings, a digital elaboration was performed over each miniature's IR reflectography results - digital reconstruction - with an image processing software. Visible images and digital reconstructions were compared. For the representation of the Adoration of the Magi (f.11), micro-sampling was performed considering both the need of representativeness, the importance of minimum intervention and the sample minimum amount required for each analytical technique. To infer on the consistency of the materials used to produce the illuminations, three representative coloured paints (white, blue and gilding) were also micro-sampled from the Pietà (f.47v) and the Pentecost (f.65v). SEMEDS, Raman microscopy (RM) and $\mu$-FTIR analysis were performed in the micro-samples.

\subsection{Selected painted illustrations}

From the 30 images present in Inc.439, a set of three painted illustrations representative of different sizes and painting techniques were chosen to be analysed by IR reflectography: the Adoration of the Magi (f.11), the Pietà $(f .47 \mathrm{v})$ and the Pentecost $(f .65 \mathrm{v})$ (Fig. 2).

The Adoration of the Magi $(60 \times 84 \mathrm{~mm})$ (Fig. 3a) is not only the major illuminated representation of Inc. 438 , but also the one that presents the most detailed painted illustration and the

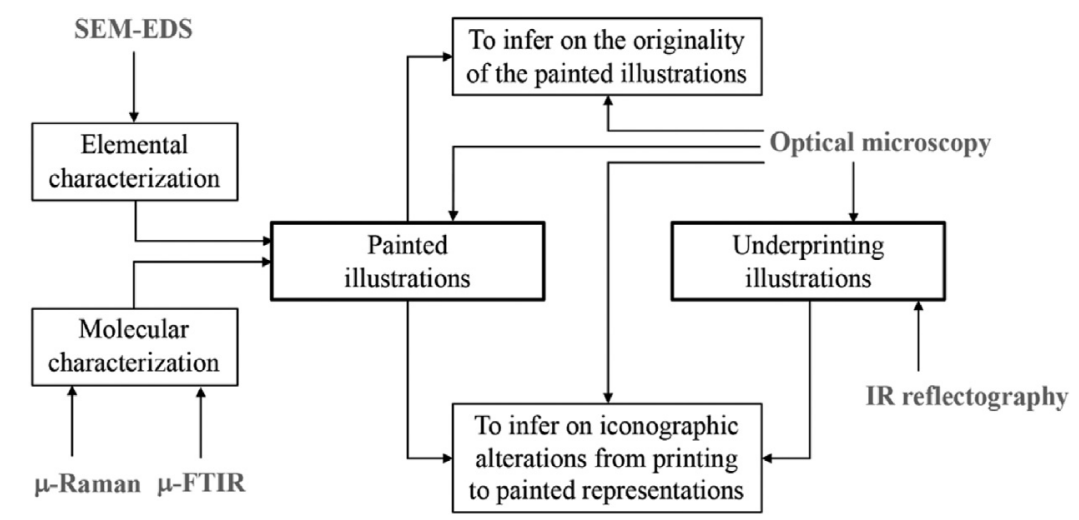

Fig. 1. Experimental design followed on the physical-chemical analysis of the Adoration of the Magi (Inc.438, f.11). 

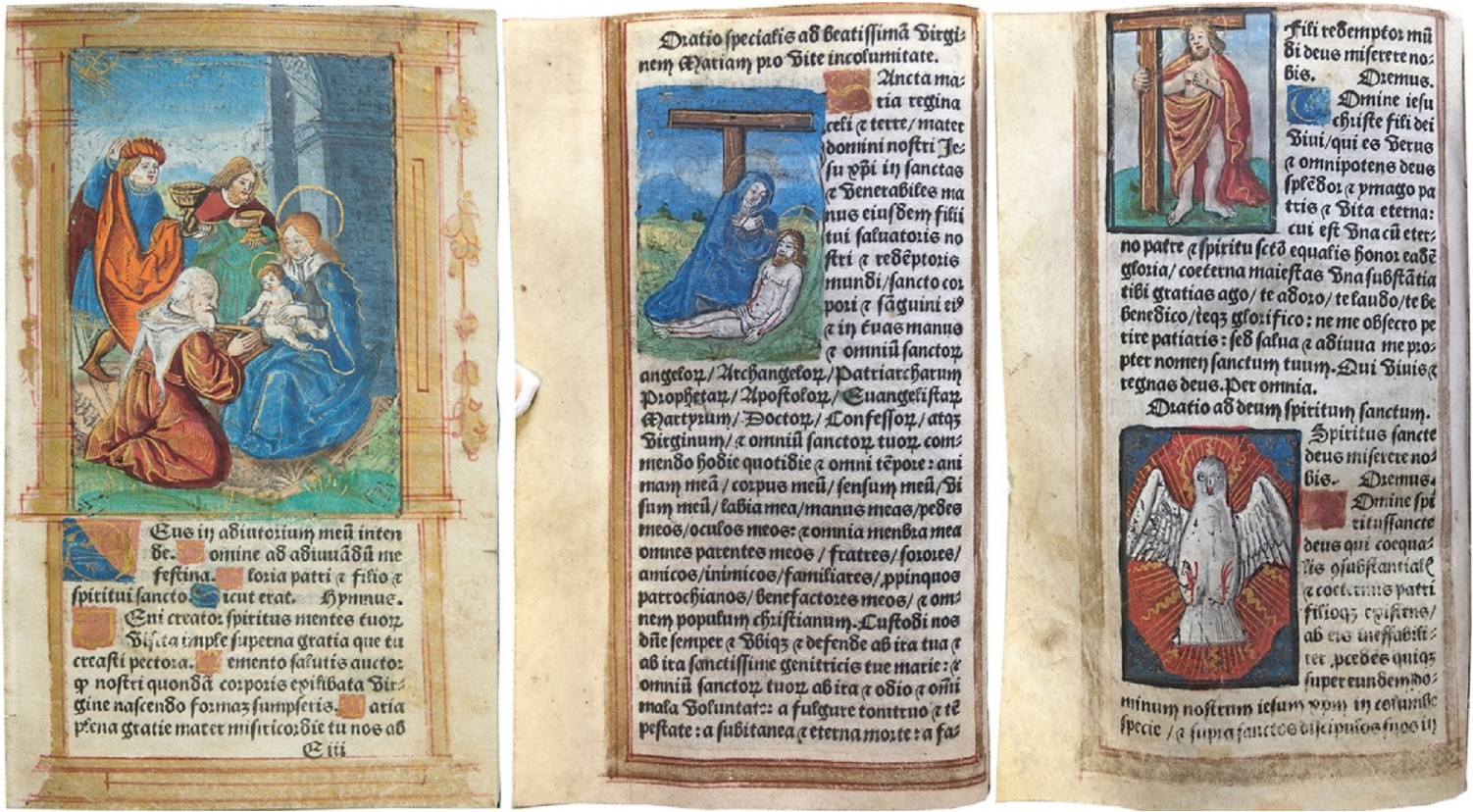

Fig. 2. Full-size images of the selected folia from Inc.438 $(170 \times 103 \mathrm{~cm})$. From left to right, the Adoration of the Magi (f.11), the Pietà $(f .47 \mathrm{v})$ and the Pentecost $(f .65 \mathrm{v})$. Photo CHERCULES Lab and BPE.
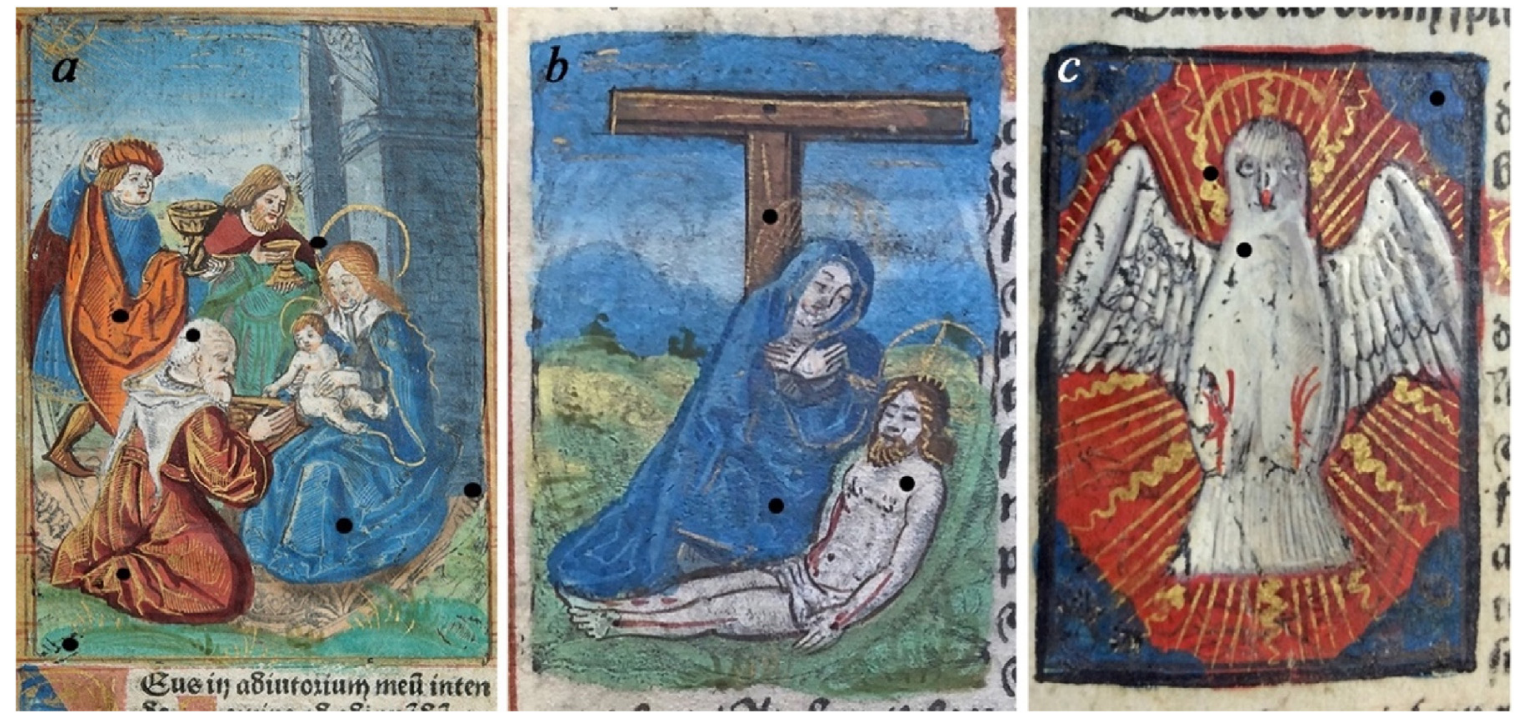

Fig. 3. Close-up images of the selected painted illustrations from Inc.438, representative of different sizes and painting techniques present in the incunabulum: a: the Adoration of the Magi (f.11); b: the Pietà (f.47v) and; c: the Pentecost (f.65v). Black marks represent the spots where material characterization was performed.

most representative of the full-palette used to produce Inc. 438's illuminations. As for the Pietà $(31 \times 52 \mathrm{~mm})$ and the Pentecost $(34 \times 47 \mathrm{~mm})$ (Fig. $3 \mathrm{~b}$ and c) they present similar dimensions, but different painting techniques: while for the Pietà $(f .47 \mathrm{v})$ detailed painting layers were used for the illustrations-close to those found in the Adoration of the Magi (f.11), for the Pentecost (f.65v) thick and inexpressive painting layers were used to produce the illumination (Fig. 3).

Aiming to evaluate the originality of the materials used to produce the coloured surfaces, namely pigments and binders, spectroscopic analysis was performed on a set of representative micro-samples of different colour paints from the Adoration of the Magi (f.11) (Fig. 3a). For the comparative analysis of the painted surfaces of the three selected illuminations, three representative colours were selected: white, blue and gilding. Fig. $3 \mathrm{~b}$ and c displays the spots where micro-sampling was performed.

\subsection{Optical microscopy and micro-sampling}

To evaluate the brushstrokes and painting techniques, the conservation state of the colour-paints and the relation between painted delimitations and underprintings, magnified images were acquired under a LEICA M205C stereomicroscope with a zoom range of $7.8 \times$ to $160 \times$ equipped with a Leica DFC295 camera and an external illumination by optical fibres. Micro-sampling was performed in lacunas with a micro chisel from Ted Pella micro tools 
(micro-samples ranging between 20-50 $\mu \mathrm{m}$ ) under the same stereoscope LEICA M205C equipped with a Leica DFC295 camera and an external illumination by optical fibres.

\subsection{Elemental characterization}

Scanning electron microscopy coupled with energy-dispersive X-ray spectroscopy (SEM-EDS) was used to characterize the elemental composition of gildings and its surface morphology. SEM-EDS analyses were performed with a variable pressure scanning electron microscope HITACHI $3700 \mathrm{~N}$ coupled to an energy dispersive X-ray spectrometer BRÜKER Xflash 5010 SDD. Uncoated samples were analysed under air pressure of $40 \mathrm{~Pa}$. The backscattering mode was used for SEM imaging. The resolution of the EDS detector is $123 \mathrm{eV}$ at the $\mathrm{Mn} \mathrm{K} \alpha$ line energy. To collect X-ray emissions from heavier elements like $\mathrm{Pb}$, an acceleration voltage of $20 \mathrm{kV}$ was chosen. The EDS tasks and the quantification were achieved through the Esprit1.9 software from BRÜKER Corporation.

\subsection{Molecular characterization}

Raman microscopy was used to characterize the chromophores (pigments and dyes) present in the paints. A Raman spectrometer HORIBA XPlora equipped with a diode laser of $10.3 \mathrm{~mW}$ operating at $785 \mathrm{~nm}$, coupled to an Olympus microscope was used for the analysis of the paint cross sections. Raman spectra were acquired in extended mode in the $100-2000 \mathrm{~cm}^{-1}$ region, using the LabSPEC5 software. The laser was focused with an Olympus $50 \times$ lens, 1-10\% of the laser power on the sample surface ( $10 \mathrm{~s}$ of exposure, 10 cycles of accumulation).

Fourier-transformed infrared spectroscopy ( $\mu$-FTIR) was used to gather information on the binders and extenders used in the paints' production. An infrared spectrometer BRÜKER Hyperion 3000 equipped with a single point MCT detector cooled with liquid nitrogen and a $15 \times$ objective lens was used. The spectra were collected in the transmission mode, in $50-100 \mu \mathrm{m}^{2}$ areas, using a S.T. Japan diamond anvil compression cell. Infrared spectra were acquired with a spectral resolution of $4 \mathrm{~cm}^{-1}, 32$ scans, in the 4000 $650 \mathrm{~cm}^{-1}$ of the infrared region, using the OPUS 7.2 software.

\subsection{Underprintings assessment}

For the underprintings assessment, a high-resolution IR reflectography camera OSIRIS equipped with an InGaAs detector sensitive between 900 and $1700 \mathrm{~nm}$ and a $16 \times 16$ tile system were used. To ensure that the total light that reach the detector does only concern infrared radiation, the original set up of the system is equipped with a long pass filter Schott RG850 to block the wavelength below $850 \mathrm{~nm}$. The camera is equipped with a PhaseOne $120 \mathrm{~mm}$ macro lens, allowing to collect high-resolution close-ups mosaic sections with $4096 \times 4096$ pixels/each before merging. For this, each representation was analysed in $5 \times 5 \mathrm{~mm}$ high-resolution mosaic sections reflectograms: for the Adoration of the Magi (acquired painted area of $60 \times 84 \mathrm{~mm}$ ), a total of 234 mosaic sections $(13 \times 18$ mosaic sections were merged to obtain the final image) were acquired for the entire representation; the Pietà (acquired painted area of $31 \times 52 \mathrm{~mm}$ ) was full screened with 77 mosaic sections $(7 \times 11$ mosaic sections were merged to obtain the final image); and the Pentecost (acquired painted area of $34 \times 47 \mathrm{~mm})$ with 70 mosaic sections $(7 \times 10$ mosaic sections were merged to obtain the final image). To create the final mosaicked image, mosaic section reflectograms were merged in a unique high definition reflectogram using an image processing software (Adobe Photoshop CS8). For this, sections of the borders of each mosaic section (varying from $0.5-1 \mathrm{~mm}$ ) were removed to ensure the best overlapping needed to merge all the sections.
After merging, very high-resolution images were obtained for each representation: the Adoration of the Maggi, 43256 pixels $\times 64400$ pixels; the Pietà, 34133 pixels $\times 45056$ pixels; and the Pentecost, 28672 pixels $\times 40960$ pixels. To make easier to manipulate each final mosaicked reflectogram, images' resolutions were decreased to 3893 pixels $\times 5796$ pixels for the Adoration of the Maggi, 3072 pixels $\times 4096$ pixels for the Pietà, and 2560 pixels $\times 3584$ pixels for the Pentecost.

Reflectograms were acquired with a working distance of $6.5 \mathrm{~cm}$. The diaphragm aperture was maintained at $F / 8$. A slow scan of 10 minutes per area and an integration time of $10 \mathrm{~m} / \mathrm{s}$ was used. The diffuse illumination system was composed of two $1000 \mathrm{~W}$ Tungsten Halogen VC-1000Q Quartz light system (3200 K colour temperature). To ensure a homogeneous illumination all over the surface of $50 \mathrm{~Hz}$, a lux meter was used. To reduce undesired reflections of light, the lamps were empirically disposed to create an angle of incidence at around $50^{\circ}$. The distance between the lamps and the object was set to provide the best covering illumination and the lowest surface temperature increase. The surface temperature of the object was consistently controlled by using an in-situ laser temperature reading (surface temperature was never overpassing more than $5 \%$ of room temperature).

For the digital reconstructions of the underprintings, an image processing software (Adobe Photoshop CS8) was used. Each final mosaicked reflectogram was increased up to $900 \%$ of magnification, and a new transparent layer applied over it. Visible image and final mosaicked reflectogram were compared. The revealed underprintings were hand-drawn on the transparent layer, with a pad-pencil tool. Hand-drawing digital reconstruction was performed for each entire miniature.

\section{Results}

As the Adoration of the Magi,f.11, evidences the best representativeness of the full-palette used to produce Inc 438's illuminations, a full characterization of the materials used to produce its coloured paints was performed. RM together with SEM-EDS and $\mu$-FTIR allowed to identify the most common materials used on Renaissance illuminations in the paints' composition of the Adoration of the Magi, f.11 (Table 1).

White was produced with lead white $\left(2 \mathrm{PbCO}_{3} \cdot \mathrm{Pb}(\mathrm{OH})_{2}\right)$, orange with red lead $\left(\mathrm{Pb}_{3} \mathrm{O}_{4}\right)$, red with vermilion $(\mathrm{HgS})$, browns with goethite $(\alpha-\mathrm{FeO}(\mathrm{OH}))$, blue with azurite $\left(2 \mathrm{CuCO}_{3} \cdot \mathrm{Cu}(\mathrm{OH})_{2}\right)$ and green with malachite $\left(\mathrm{Cu}_{2} \mathrm{CO}_{3}(\mathrm{OH})_{2}\right)$. Raman microscopy identified the presence of two different yellows: massicot $(\beta-\mathrm{PbO}$, orthorhombic) and lead tin yellow (type I) ${ }^{1}$ (Fig. 4).

Black was produced with a carbon black of animal origin. For lighter greens, a mixture of malachite, lead tin yellow (type I) and massicot was found. For the darker blues, a mixture of azurite and indigo was found. Fig. 5 presents the representative Raman spectrum of indigo, where its characteristic bands at $1573 \mathrm{~cm}^{-1}$ ascribed to the $v(\mathrm{C}=\mathrm{C})$ stretching vibrations, the two characteristic bands assigned to the bending vibrations involving the central $\mathrm{C}=\mathrm{C}$ bonds, and the out-of-plane bending involving the five membered-ring at $549 \mathrm{~cm}^{-1}$ and $597 \mathrm{~cm}^{-1}$, were identified $[18,19]$.

\footnotetext{
${ }^{1}$ Lead tin yellow was the wildest used synthetic yellow pigment during the Renaissance (notably in the period 1300-1750). Depending on the recipe followed for its production, two types can be found: type I and type II. The first is a tin stannate with general formula $\mathrm{Pb}_{2} \mathrm{SnO}_{4}$. The second is a tin oxide with silicon in its composition, with general formula $\mathrm{Pb}(\mathrm{Sn}, \mathrm{Si}) \mathrm{O}_{3}$ [17]. SEM-EDS analysis of lead tin yellow from Inc. 438 did not identify the presence of silicon, pointing to the presence of type I in the light-yellow paints.
} 
Table 1

Close-up details, pigments and dyes found in illuminations of the Adoration of the Magi, f.11.

\begin{tabular}{|c|c|c|}
\hline Detail & Colour & Pigment/dye \\
\hline & White & Lead white \\
\hline & Gilding & Au: Ag: Cu (96:2:2, \%wt) \\
\hline
\end{tabular}

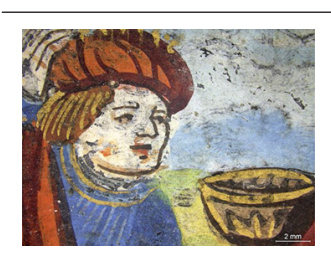

\begin{tabular}{ll} 
Pale yellow & Massicot \\
\hline Yellow & Lead tin yellow (type I)
\end{tabular}

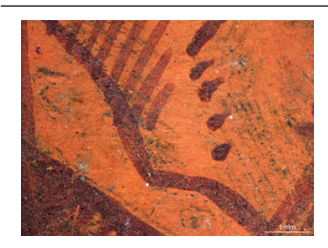

\begin{tabular}{ll} 
Orange & Red lead \\
\hline Red & Vermilion
\end{tabular}

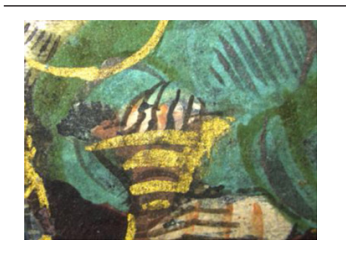

Light green Malachite + Lead tin yellow (type 1$)+$ Massicot

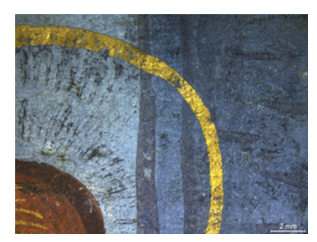

\begin{tabular}{ll} 
Blue & Azurite \\
\hline Dark blue & Indigo + Azurite
\end{tabular}

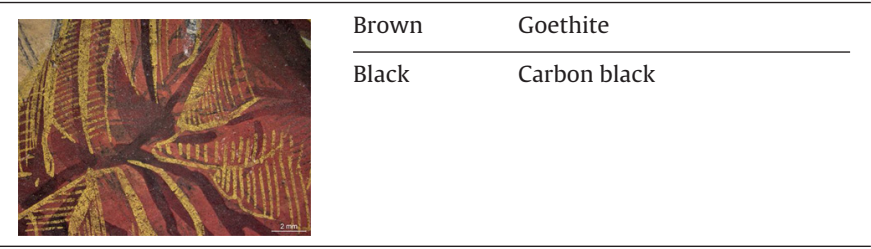

Gildings were produced with a high-pure gold alloy (Au:Ag:Cu, 96:2:2, wt\%) in the form of flake-shape particles characteristic of powdered gold, identified by SEM-EDS (Fig. 6).

FTIR analysis of representative paint micro-samples allowed to identify paints produced in a polysaccharide medium, often mixed with chalk as extender (Fig. 7).

Together with the printing ink formulation - a carbon black enriched iron gall ink - the materials used to produce the painted surfaces enabled the fundamental IR reflectance/transparency for characterizing the printing technique [16].

The comparative elemental (SEM-EDS) and molecular (RM and $\mu$-FTIR) analysis of three selected colours (white, blue and gilding) from three illustrations (the Adoration of the Magi, the Pietà and the Pentecost) revealed the use of comparable materials: whites were produced with lead white, blues with azurite and gildings with a gold alloy, in a polysaccharide medium (Table 2).

Up to the $18^{\text {th }}$ century, gold leaf was mainly produced from beaten-gold coins [20]. Pure gold that was seldom used and

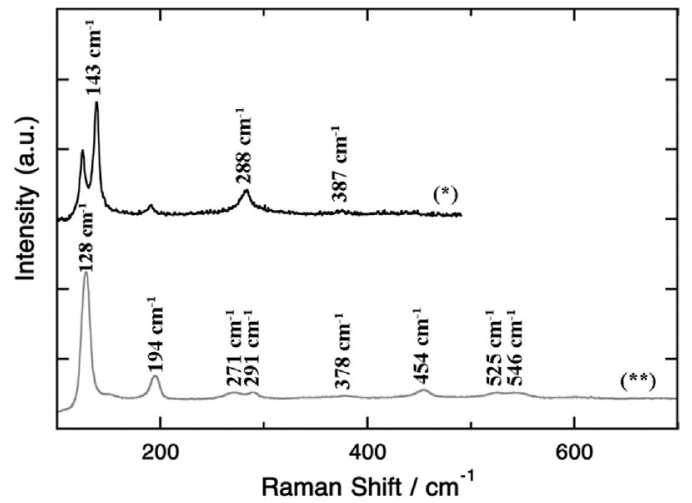

Fig. 4. Raman spectra of two yellow paints' micro-samples from $f .11$, evidencing the characteristic Raman bands of massicot $\left(^{*}\right)$ and of lead tin yellow (type I $\left({ }^{* *}\right)$ ).

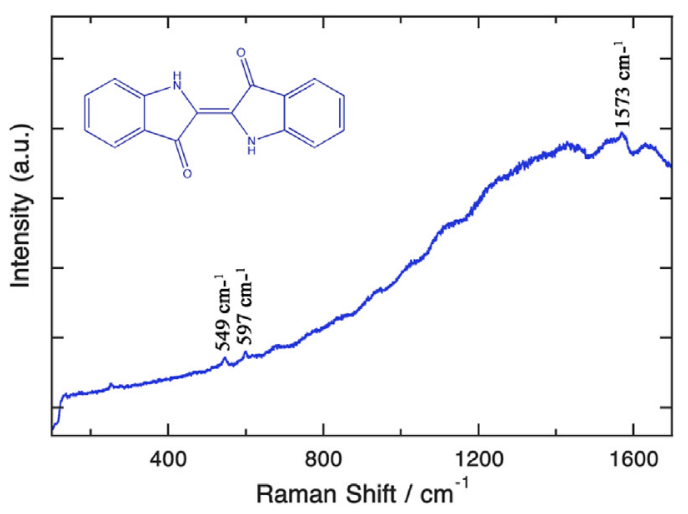

Fig. 5. Raman spectrum of a darken blue paint from $f .11$, evidencing the characteristic Raman bands of indigo. The inset, molecular structure of indigo.

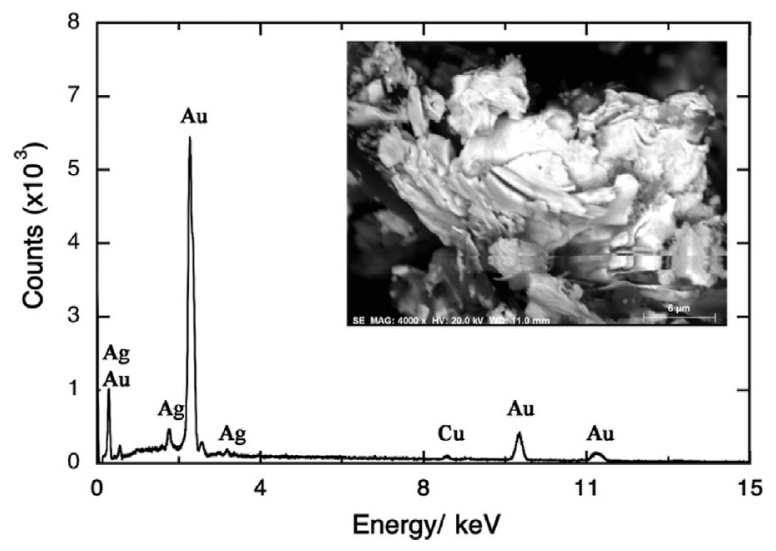

Fig. 6. SEM-EDS results of a gilding paint micro-sample from $f .11$, evidencing the use of powder gold-alloy for the gildings.

restricted to the most important artworks' production. From the analysis of elemental composition of the gilding paints present in Table 2, it is possible to conclude that gildings were produced with very pure gold alloys of similar compositions, presenting minor amounts of $\mathrm{Cu}$ (copper) and $\mathrm{Ag}$ (silver). It is thus expected that these gildings were applied in a near period, being the differences in the alloy composition probably related to the use of different batches to produce these paints. 


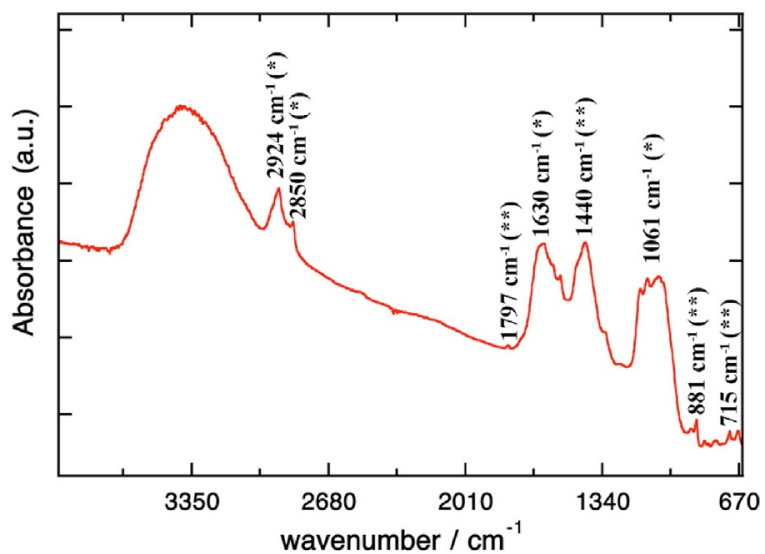

Fig. 7. Infrared spectrum of a red paint micro-sample from $f .11$, evidencing the characteristic absorption bands of a polysaccharide binder $\left(^{*}\right)$ and chalk $\left(^{* *}\right)$ as extender.

\section{Table 2}

Close-up details and comparative results of the pigments used to produce white, blue and gildings in the Adoration of the Magi (f.11), the Pietà (f.47v) and the Pentecost (f.65v).

\begin{tabular}{|c|c|c|c|}
\hline Folium & Detail & Colour & Pigment/dye \\
\hline \multirow[t]{3}{*}{11} & & White & Lead white \\
\hline & & Gilding & $\begin{array}{l}\text { Au: } \mathrm{Ag}: \mathrm{Cu} \\
\text { (96:2:2,\%wt) }\end{array}$ \\
\hline & & Blue & Azurite \\
\hline \multirow[t]{3}{*}{$47 v$} & & White & Lead white \\
\hline & & Gilding & $\begin{array}{l}\mathrm{Au}: \mathrm{Ag}: \mathrm{Cu} \\
(95: 3: 2, \% w t)\end{array}$ \\
\hline & & Blue & Azurite \\
\hline \multirow[t]{3}{*}{$65 v$} & & White & Lead white \\
\hline & & Gilding & $\begin{array}{l}\text { Au: } \mathrm{Ag}: \mathrm{Cu} \\
(98: 1: 1, \% w t)\end{array}$ \\
\hline & & Blue & Azurite \\
\hline
\end{tabular}

\subsection{The printing technique}

The printing technique: Magnified observation of the illustrations under a stereomicroscope allowed to identify the presence of underprintings in regions of lacunas and thinner paints (Fig. 8). If in some of the regions the underprintings closely match the painted illustrations (or even, for thinner paint layers, underprintings work as darken shades on the paints' composition (Fig. 8a yellow circle)), in other regions the underprintings were not respected by the illuminator (Fig. 8b and c, yellow circles). Besides, it was possible to observe that the printing process was performed straight on the parchment, without any preparation layer.

IR reflectography was crucial for characterizing the printing process followed by Germain Hardouyn. Fig. 9 displays the visible image of the Adoration of the Magi, its IR reflectography and the digital reconstruction of the underprintings recovered from IR reflectography results. The first impact of the comparison between the illuminated representation (visible image, Fig. 9a) and the underprintings' digital reconstruction (Fig. 9c) comes from the loss of detail of the decorative motifs: the printed version is considerable more detailed than the painted illustration. Also, interesting alterations on the iconographical programme of the printed version were revealed: somehow during the illumination procedure, the artist opted to omit some of the most characteristic iconographical motifs related with the Adoration of the Magi, such as the Star (which guided the Magi to the place where Jesus Christ was born), Saint Joseph (that should be next to the Virgin Mary when the Magi arrived to the place), or the saber - a curved blade sword with a single cutting edge traditional of the Eastern world - sheathed by the elder Magus as a sign of his provenance from the Eastern world.

Remarkable similarities were found between the underprintings digital reconstruction recovered from the IR reflectography of Inc. 438, f.11 (Fig. 9c) and the same scene represented in a nonpainted incunabulum produced by Germain Hardouyn c. 1532 [2] (Fig. 10).

Such matching supports the use of the same engraving composition (main scene and frames) for printing several incunabula. In fact, this illustration integrates a complete Medallion series for octavesized books made by an anonymous artist for Germain Hardouyn in 1516, but firstly used after 1526 [2]. In this sense, Inc. 438 might have been printed in the late first-half of the sixteenth century, and not in an earlier period. Regarding the iconographic programme of the painted representation (Fig. 9a), considerable similarities were found with another incunabulum printed by Germain Hardouyin in c.1535, including the non-representation of Saint Joseph, the saber and the Star [21]. Despite the differences of brushstrokes in both illuminations, these similarities could date the painted illustration back to mid 1530's.

Also, for the representation of the Pietà $(f .47 \mathrm{v})$ and the Pente$\operatorname{cost}(f .65 \mathrm{v})$, remarkable alterations on the iconographic programme of the printed representations were unveiled with the underprintings digital reconstruction recovered from IR reflectography (Figs. 11 and 12). In fact, while the printers followed an iconographic programme very close to the references from the Holy Scriptures, the illuminator tended to follow related iconographies more in fashion at the time of the production of the incunabulum. Considering the representation of the Pietá (which accompanies the text of the Lamentation of Christ), the underprintings recovered from IR reflectography brought to light the scene referred in the Gospel according to Saint Mathews, where after Christ death, Joseph of Arimathea took Christ's body and placed it in a new tomb cut off on a rock, opposite to where Mary Magdalene and the other Mary were sited (Mt.27, 57-61) (Fig. 11c). In this reference, there is no mention to the fact that the Virgin Mary have carried the Body of Christ, but the Tradition of the Church often represents this scene with Christ laid down on the Virgin Mary's arms, flanked by Mary Magdalene and another character, usually representing John the Evangelist. In Inc.438 (f.47v) the illuminator refused the presence of these two flanking characters, highlighting the figure of the Pietá (the Virgin Mary holding the body of Her son Jesus Christ) as the main character of the scene (Fig. 11a).

This is much in line with devotion to the representation of the Pietà during the early sixteenth century, which achieved its highest representation with Michelangelo's sculpture produced between 1499-1500 [22].

For the Pentecost $(f .65 \mathrm{v})$ - the moment when the Holy Spirit descent on the Apostles - it is usually represented by the Virgin Mary surrounded by the Apostles and the Holy Spirit on the top of the composition, from Whom comes out rays representing the seven Gifts of the Holy Spirit spread over the Apostles (the Gifts of Wisdom, Understanding, Counsel, Fortitude, Knowledge, Piety and Fear of the Lord). Again, likewise seen for the Pietà, this was the iconography of the underprintings which IR reflectography brought to light (Fig. 12c). Nevertheless, and likewise for the Pietà, the 

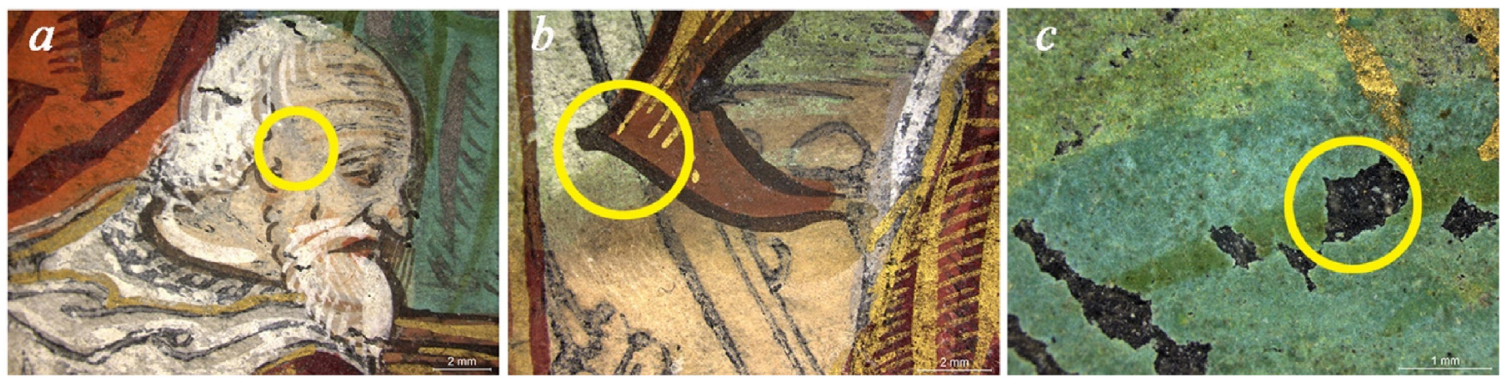

Fig. 8. Signs of underprintings at the Adoration of the Magi (Inc. 438, f.11).
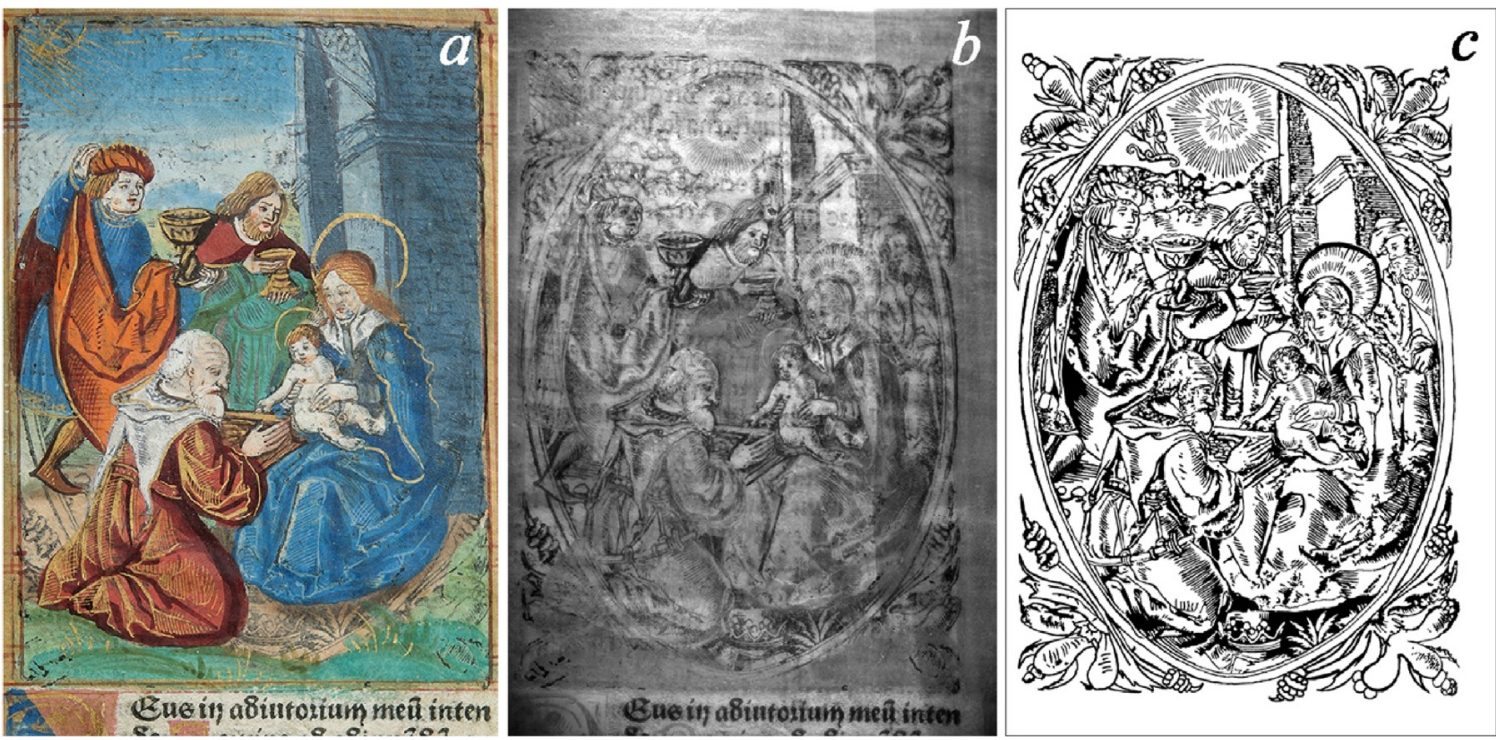

Fig. 9. The Adoration of the Magi (Inc. 438, f.11): a: visible image; b: infrared reflectography; c: digital reconstruction of the underprintings of the Adoration of the Magi. Photo CHERCULES Lab and BPE.
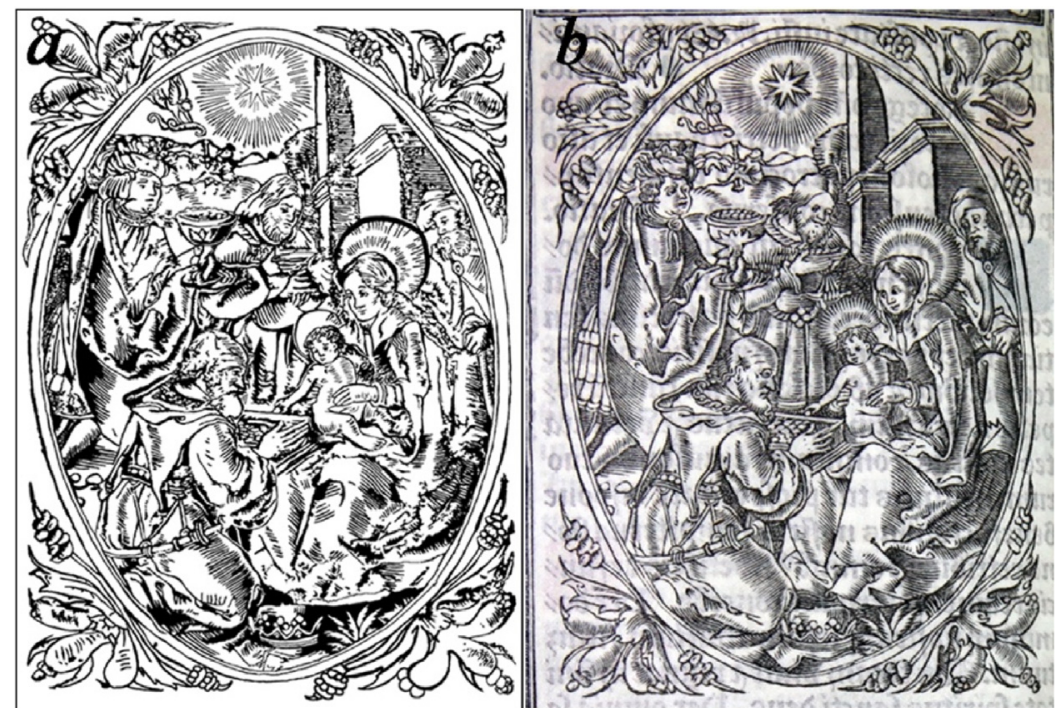

Fig. 10. The Adoration of the Magi: a: digital reconstruction of the underprintings of the Adoration of the Magi in Inc. 438, $f .11$; b: printed illustration in a Book of Hours, use of Rome. Paris, c. 1532 [2].

illumination of the printed representation was completely changed, as the image represents a dove - the Holy Spirit surrounded by rays (Fig. 12a). The Devotion to the Holy Spirit was specially influenced during the Pontifex of Pope Pius V, who strongly believed that if Christians invoked the Holy Spirit with contrite hearts, numerous graces would be favoured to them. As Pope Pius V Pontifex last between 1566 to 1572 , the influence of this devotion could place the process of illuminating to a later period 

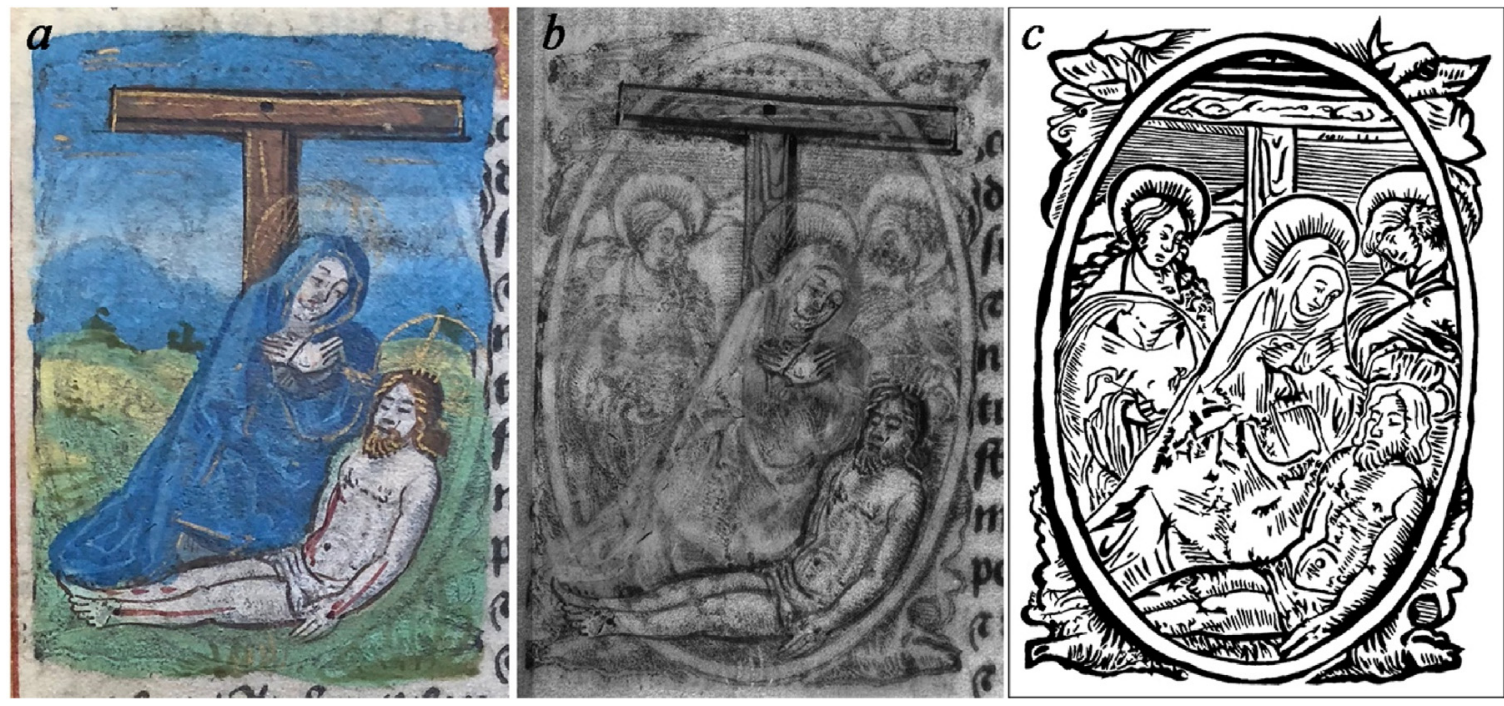

Fig. 11. The Pietà (Inc. 438, f.47v): a: visible image; b: infrared reflectography; c: digital reconstruction of the underprintings of the Pietà. Photo @HERCULES Lab and BPE.
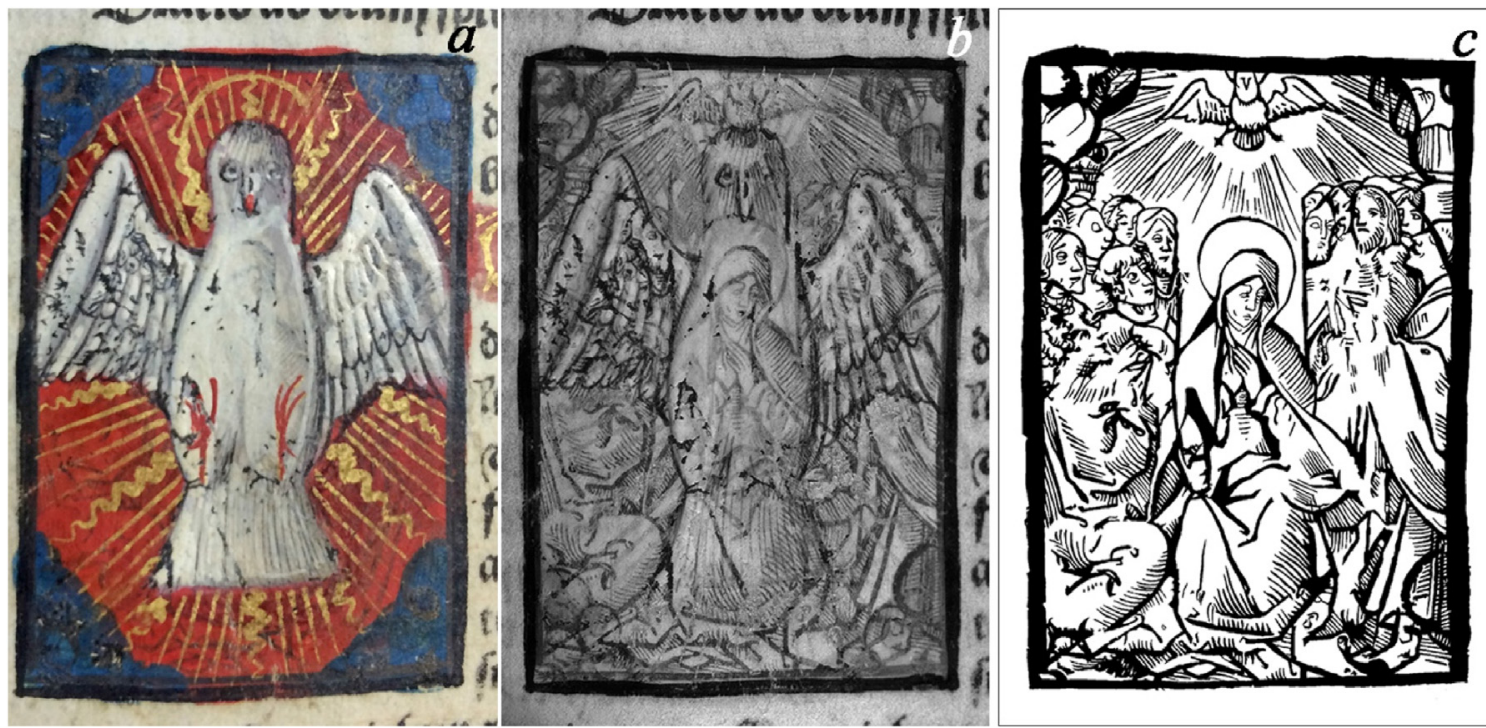

Fig. 12. The Pentecost (Inc. 438, f.65v): a: visible image; b: infrared reflectography; c: digital reconstruction of the underprintings of the Pentecost. Photo ${ }^{\circ}$ HERCULES Lab and BPE.

of the printing process. At the same time, it should not be discharged a possible influence of the Council of Trent (1545-1563) on the iconographical alterations of the representations present in Inc.438, as a consequence of its statements and clarifications regarding the Church's doctrine, teachings and praying practices, including subjects as the veneration of saints and representations of biblical scenes.

Comparing the painting techniques followed for producing the illuminations of the Adoration of the Magi $(f .11)$, the Pietà $(f .47 \mathrm{v})$ and the Pentecost (f.65v) (Figs. 9a, 11a and 12a), it is quite likely that two different hands might have worked on this process. While for the Adoration of the Magi and the Pietà, the paints are thin (for a reasonable area of painted area, the paints appear to have been applied as aquarelle with visible details of underprintings) with delicate brushstrokes, for the Pentecost $(f .65 \mathrm{v})$ the paints become ticker, applied with coarse brushstrokes. Despite not have been possible to identify differences on the materials used to produce the three illuminations, there might have been two different persons producing these illuminations, probably in a different time, but in a close period.

\section{Conclusions}

The use of IR reflectography for analysing the production technique of incunabula revealed to be an important and powerful tool. It was possible to identify the presence of underprintings that largely differed from the visible illuminated representations. Based on the analysis of both iconographies (printed and illuminated representations), it is possible to conclude that the illuminator was strongly influenced by the devotions that were in fashion at the time, unlike the engraving plates whose representations faithfully follow the references of the Holy Scriptures, particularly for the Pietà and the Pentecost, whose iconographic alterations might have been done in a later period. The underprintings digital reconstruction recovered from IR reflectographies for the BPE Inc.439, a Book of Hours produced by Germain Hardouyn, revealed the procedures used for these first printed books' production - the best testimonies of the transition of medieval illuminated manuscripts to the printing books. As for the illumination procedures, the full characterization of the materials used to produce the illustrations of the Adoration of the Magi reflected the use of high-quality materials, 
in agreement with those in fashion at the time. The comparison of the materials used to produce white, blue and gilding paints for the three illuminations reflected the use of similar materials, supporting the idea that these painted illustrations might have been painted in a relatively close period, but by a different illuminator.

\section{Acknowledgments}

The authors thank to Sonia Costa for the contributions with the reflectographies' acquisitions, to Dr. Tenschert for providing without publication fees the image of the Adoration of the Magi present in a Book of Hours, use of Rome, Paris, c. 1532 (Fig. 10b), and to Biblioteca Pública de Évora (BPE) the access and all the support during the study of Inc.438. Finally, the authors thank the FCT for financial support under the UID/Multi/04449/2013 (POCI-010145-FEDER-007649) project. Catarina Miguel thanks the FCT for financial support under grant SFRH/BPD/92865/2013.

\section{References}

[1] C. Zöhl, J. Pichore, Buchmaler, Graphiker Und Verleger in Paris Um 1500, Brepols Publishers, Turnhout, 2004 (ISBN: 2503521940).

[2] H. Tenschert, I. Nettekoven, Horae BMV: 158 Stundenbuchdrucke der Sammlung Bibermühle, Vol. VIII, Antiquariat Heribert Tenschert, Rotthalmünster, 2003, pp. 3366-3378 (ISBN: 2503521940).

[3] H. Mommsen, T.H. Beier, H. Dittmann, D. Heimermann, A. Hein, A. Rosenberg M. Boghardt, E.-M. Hanebutt-Benz, H. Halbey, X-ray fluorescence analysis with synchrotron radiation on the inks and papers of incunabula, Archaeometry 38 (1996) 347-357, http://dx.doi.org/10.1111/j.1475-4754.1996.tb00782.x.

[4] V. Reinburg, French books of hours: making an archive of prayer, c, 1400-1600, Cambridge University Press, Cambridge, 2012 (ISBN: 9781107007215)

[5] C. De Hamel, A history of illuminated manuscripts, Phaidon Press, London, 1997 (ISBN: 0714834521).

[6] T.A. Cahill, B.H. Kusko, R.A. Eldred, R.N. Schwab, Guttenberg's inks and papers non-destructive compositional analysis by proton milliprobe, Archaeometry 1 (1984) 3-14, http://dx.doi.org/10.1111/j.1475-4754.1984.tb00312.x.

[7] M.V. Mendes, Os Incunábulos das Bibliotecas Portuguesas. Inventário do Património Móvel, first ed. Secretaria de Estado da Cultura-Instituto da Biblioteca Nacional e do Livro, Lisboa, Vol. 1, 1995 (ISBN: 972-565-214-2).

[8] I. Cid, Incunábulos da Biblioteca Pùblica e Arquivo Distrital de Évora: Catálogo Abreviado, BPADE, Évora, 1988.

[9] S. Valadas, R. Freire, A. Cardoso, J. Mirão, P. Vandenabeele, J.O. Caetano, A Candeias, New insight on the underdrawing of 16th Flemish-Portuguese easel paintings by combined surface analysis and microanalytical techniques, Micron 85 (2016) 15-25, http://dx.doi.org/10.1016/j.micron.2016.03.004.

[10] F. Mercuri, et al., Metastructure of illuminations by infrared thermography, J. Cult. Herit. 31 (2018) 53-62, http://dx.doi.org/10.1016/j.culher.2017.10. 008 .

[11] V. Antunes, A. Candeias, J. Mirão, L. Maria, C. Carvalho, A. Barrocas Dias, A Manhita, M.J. Cardoso, A. Francisco, M. Lauw, Manso, Analytical characterization of the palette and painting techniques of Jorge Afonso, the great 16th century Master of Lisbon painting workshop, Spectrochim. Acta A Mol. Biomol. Spectrosc. 193 (2018) 264-275, http://dx.doi.org/10.1016/j.saa.2017.12. 027

[12] M. Gargano, F. Cavaliere, D. Viganò, A. Galli, N. Ludwig, A new spherical scanning system for infrared reflectography of paintings, Infrared Phys. Technol. 81 (2017) 128-136, http://dx.doi.org/10.1016/j.infrared.2016.12.011.

[13] F. Mercuri, S. Paoloni, C. Cicero, U. Zammit, N. Orazi, Infrared emission contrast for the visualization of subsurface graphical features in artworks, Infrared Phys. Technol. 89 (2018) 223-230, http://dx.doi.org/10.1016/j.infrared.2018.01.012.

[14] M. Gargano, D. Bertani, M. Greco, J. Cupitt, D. Gadia, A. Rizzi, A perceptual approach to the fusion of visible and NIR images in the examination of ancient documents, J. Cult. Herit. 16 (2015) 518-525, http://dx.doi.org/10.1016/j.culher.2014.09.006.

[15] F. Albertin, E. Balliana, G. Pizzol, G. Colavizza, E. Zendri, D. Raines, Printings materials and technologies in the 15th-17th century book production: an undervalued research field, Microchem. J. 138 (2018) 147-173, http://dx.doi.org/10.1016/j.microc.2017.12.010.

[16] M. Gargano, N. Ludwig, G. Poldi, A new methodology for comparing IR reflectographic systems, Infrared Phys. Technol. 49 (2007) 249-253, http://dx.doi.org/10.1016/j.infrared.2006.06.013.

[17] N. Eastaugh, V. Walsh, T. Chaplin, R. Siddall, The pigment compendium-A dictionary of historical pigments, Elsevier Butterworth-Heinemann, Burlington, 2004, pp. 237-238 (ISBN: 978-0-7506-8980-9).

[18] M. Leona, F. Casadio, M. Bacci, M. Picollo, Identification of the Pre-Columbian Pigment Maya Blue on works of art by noninvasive UV-Vis and Raman Spectroscopic Techniques, J. Am. Institute Conserv. 43 (1) (2004) 39-54, http://dx.doi.org/10.2307/3179850.

[19] A. Amat, F. Rosi, C. Miliani, A. Sgamellotti, S. Fantacci, Theoretical and experimental investigation on the spectroscopic properties of indigo dye, J. Mol Structure 993 (2011) 43-51, http://dx.doi.org/10.1016/j.molstruc.2010.11. 046.

[20] A. Le Gac, A.I. Seruya, M. Lefftz, A. Alarcão, The main altarpiece of the Old Cathedral of Coimbra (Portugal): characterization of gold alloys used for gilding from 1500 to 1900, ArcheoSci. Rev. Archeometr. 33 (2009) 423-432, http://dx.doi.org/10.4000/archeosciences.2562.

[21] H.W. Davies, Catalogue of a collection of early French books in the library of C. Fairfax Murray, Privately printed, London, 1910 (ISBN: 1578981778).

[22] J.E. Ziegler, Michelangelo and the Medieval Pietà: the sculpture of devotion or the art of sculpture, Gesta 34 (1) (1995) 28-36, http://dx.doi.org/10.2307/767122. 